\title{
Lymphoid Enhancer-Binding Factor 1
}

National Cancer Institute

\section{Source}

National Cancer Institute. Lymphoid Enhancer-Binding Factor 1. NCI Thesaurus. Code C80034.

Lymphoid enhancer-binding factor 1 (399 aa, 44 kDa) is encoded by the human LEF1 gene. This protein is involved in Wnt signaling and transcriptional regulation. 